Present and Future Carbon Balance of Russia's Northern Ecosystems Final Report DOE grant DE-FG03-95ER62014

to the University of California Berkeley

Principal Investigator: F. Stuart Chapin, III

Principal Collaborator: Sergei A. Zimov

\title{
Carbon exchange
}

Summary: Recent increases in the seasonal amplitude of atmospheric $\mathrm{CO}_{2}$ at high latitudes suggest a widespread biospheric response to highlatitude warming. We have shown that the seasonal amplitude of net ecosystem carbon exchange by northern Siberian ecosystems is greater in disturbed than undisturbed sites, due to increased summer influx and increased winter efflux. Net carbon gain in summer and respiration in winter were greater in a cool than in a warm year, especially in disturbed sites and did not differ between high-arctic and treeline sites, suggesting that highlatitude warming, if it occurred, would have little effect or would reduce seasonal amplitude of carbon exchange. We suggest that increased disturbance contributes significantly to the amplified seasonal cycle of atmospheric $\mathrm{CO}_{2}$ at high latitudes.

Most undisturbed ecosystems at high latitudes have abundant mosses, lichens, and evergreen trees or shrubs, which photosynthesize at low rates throughout the snow-free season (Oechel and Sveinbjörnsson 1978, Fan et al. 1995, Goulden and Crill In press). Mosses and the associated organic mat reduce soil thaw during summer because of their low thermal conductance, so soils freeze quickly in autumn, minimizing winter respiration (Zimov et al. 1993, Chapin et al. 1996). Even in Siberian larch forests the understory is primarily mosses and evergreen shrubs. Following disturbance at high-latitudes, there is a shift in dominance from evergreen plants to herbs, grasses, and deciduous woody species that produce leaves $2-4$ weeks after snowmelt and shed leaves 2-4 weeks prior to autumn snow cover, thus shortening the season of photosynthetic activity. These deciduous species have higher maximum rates of photosynthesis (Oberbaver and Oechel 1989) and productivity (Shaver and Chapin 1991) than mosses and evergreens. The decline in moss cover increases summer soil heat flux and delays winter freezing of soils (Zimov et al. 1993).

In recent decades disturbance has increased at high latitudes. The area burned has doubled in western and central Canada (Flannigan and Van Wagner 1991), and $50-80 \%$ of Siberian forests have burned in the last $40 \mathrm{yr}$ (Zimov et al. 1993), causing a shift from mosses to grasses and deciduous shrubs (Viereck 1973). Other disturbances include insect outbreaks, overgrazing by reindeer, and nitrogen deposition.

From June 1995 to the present we examined the relative impact of temperature and disturbance on the seasonal amplitude of carbon exchange in five undisturbed and five disturbed ecosystems in the forest tundra zone of northeast Siberia $\left(69^{\circ} \mathrm{N}, 161^{\circ} \mathrm{E}\right)$ and in four disturbed and four undisturbed sites on 


\section{DISCLAIMER}

This report was prepared as an account of work sponsored by an agency of the United States Government. Neither the United States Government nor any agency thereof, nor any of their employees, make any warranty, express or implied, or assumes any legal liability or responsibility for the accuracy, completeness, or usefulness of any information, apparatus, product, or process disclosed, or represents that its use would not infringe privately owned rights. Reference herein to any specific commercial product, process, or service by trade name, trademark, manufacturer, or otherwise does not necessarily constitute or imply its endorsement, recommendation, or favoring by the United States Government or any agency thereof. The views and opinions of authors expressed herein do not necessarily state or reflect those of the United States Government or any agency thereof. 


\section{DISCLAIMER}

Portions of this document may be illegible in electronic image products. Images are produced from the best available original document. 
the arctic coast $130 \mathrm{~km}$ to the north $\left(70^{\circ} \mathrm{N}, 161^{\circ} \mathrm{E}\right)$. Daytime carbon gain in undisturbed ecosystems in the forest tundra zone (forest tundra, bog, wetland, and shrub tundra) was compensated by a similar seasonal pattern of nighttime $\mathrm{CO}_{2}$ efflux. Consequently, average net daily flux was relatively small throughout the year. Disturbed sites differed from undisturbed sites during summer in having greater daytime $\mathrm{CO}_{2}$ influx (2.1-2.5 fold), greater nighttime $\mathrm{CO}_{2}$ efflux (1.8-2.6 fold), greater average daily $\mathrm{CO}_{2}$ influx (1.6-3.0 fold), and a 6wk shorter season of positive daytime carbon gain; winter respiration was also 4.3-fold greater in disturbed than in undisturbed sites. Thus, the seasonal amplitude of $\mathrm{CO}_{2}$ exchange (integrated summer uptake minus integrated winter efflux) was 2.3-3.3 fold greater in disturbed than in undisturbed sites (Fig. 1, Table 1).

Average daily air temperature was warmer $\left(11.3^{\circ} \mathrm{C}\right)$ and exceeded $0^{\circ} \mathrm{C}$ for two weeks longer in summer 1995 than in $1996\left(9.2^{\circ} \mathrm{C}\right)$. June and July, when growth and photosynthesis were most active, were drier in $1995(41 \mathrm{~mm})$ than in $1996(74 \mathrm{~mm})$. Daytime carbon gain and growing-season net daily carbon gain were greatest in the cool wet year (1996), whereas nighttime carbon efflux was greater in the warmer summer (1995), suggesting that respiration correlated positively with temperature, whereas photosynthesis correlated positively with precipitation, as expected in the dry Siberian climate and as we observed previously (Zimov et al. 1996). These interannual differences were larger in the disturbed than in undisturbed sites. Positive daytime carbon gain began and finished earlier in the warmer year (1995) despite warm September temperatures in that year, resulting in a similar season length of positive carbon gain in the two years. Integrated daytime carbon gain over the growing season was $10-30 \%$. greater in the cold than the warm year, whereas nighttime $\mathrm{CO} 2$ efflux was 20 $80 \%$ greater in the warm than the cold year, suggesting that respiration had a greater influence than did photosynthesis on interannual variation in growingseason net $\mathrm{CO}_{2}$ flux.

Within each year, maximum nighttime $\mathrm{CO}_{2}$ efflux coincided with maximum air temperature, and maximum net carbon gain coincided with minimum temperature, similar to the temperature responses observed between years.

Daytime $\mathrm{CO}_{2}$ influx, nighttime $\mathrm{CO}_{2}$ efflux, and average daily carbon gain during summer at the cold arctic coastal site were similar to values in forest tundra, despite an $8^{\circ} \mathrm{C}$ cooler summer temperature on the coast. As in forest tundra, daytime carbon gain, nighttime carbon loss, and net carbon gain in summer in the arctic site were greater in disturbed than in undisturbed sites.

Our results show that disturbance greatly increased the seasonal amplitude of net carbon exchange and had as great an effect on this seasonal amplitude as did either interannual or geographic differences in growingseason temperature. Moreover, there was little difference between years in length of the season of positive carbon gain, despite a 2-wk difference in length 
of time above $0^{\circ} \mathrm{C}$, suggesting that the 1-2-wk increase in time above $0^{\circ} \mathrm{C}$ and in NDVI at high latitudes (Myneni et al. 1997) might have modest effects on seasonal amplitude of net $\mathrm{CO}_{2}$ exchange.

The pattern of greater net carbon uptake in cold than in warm years is consistent with earlier observations of high efflux in warm summers (Oechel et al. 1993, Zimov et al. 1996). These results are logical consequences of the broad temperature response curve of photosynthesis in arctic plants and the enhancement of respiration in warm years due to reduced water-logging and/or the greater temperature sensitivity of respiration compared to photosynthesis Thus, in the north it is unlikely that increased warming would directly enhance summer net $\mathrm{CO}_{2}$ uptake. The disturbed sites showed greater difference in annual carbon exchange between warm and cold years $1160 \mathrm{~g} \mathrm{C}$ $\left.\mathrm{m}^{-2} \mathrm{yr}^{-1}\right)$ than did the undisturbed sites $\left(25 \mathrm{~g} \mathrm{C} \mathrm{m}^{-2} \mathrm{yr}^{-1}\right)$, suggesting that disturbance could greatly amplify the sensitivity of high-latitude carbon exchange to any future warming.

In summary, changes in species composition associated with disturbance could contribute substantially to the increased seasonal amplitude of atmospheric $\mathrm{CO}_{2}$ and of NDVI. The strong mid-summer increase in NDVI (Myneni et al. 1997) matches our pattern of carbon exchange in disturbed sites. The higher soil fertility of disturbed sites might increase their responsiveness to atmospheric $\mathrm{CO}_{2}$. Based on our observed differences in seasonal amplitude of carbon exchange between undisturbed and disturbed sites, we calculate that an approximate $20-30 \%$ increase in area disturbed could account for the observed $40 \%$ increase in seasonal amplitude of atmospheric $\mathrm{CO}_{2}$ at high latitudes. If our results are representative, changes in high-latitude disturbance regime and associated species shifts could have as great an effect on $\mathrm{CO}_{2}$ feedbacks to climate as would direct temperature effects on carbon exchange.

\section{Methane flux}

Summary: The sizes of major sources and sinks of atmospheric methane $\left(\mathrm{CH}_{4}\right)$, an important greenhouse gas, are poorly known. $\mathrm{CH}_{4}$ from north Siberian lakes contributes $\sim 2 \mathrm{Tg} \mathrm{CH}_{4} \mathrm{yr}^{-1}$ to observed winter increases in atmospheric $\mathrm{CH}_{4}$ concentration at high northern latitudes. $\mathrm{CH}_{4}$ emitted from these lakes in winter had a radiocarbon age of 27,200 years and was derived largely from Pleistocene-aged carbon.

The highest concentration and greatest seasonal amplitude of atmospheric $\mathrm{CH}_{4}$ occurs at $65-70^{\circ} \mathrm{N}$. Concentrations are highest in March-April and lowest in summer (Fung et al. 1991). Photochemical oxidation of $\mathrm{CH}_{4}$ contributes to the low summer levels (Khalil and Rasmussen 1983) but does not explain why the seasonal amplitude of atmospheric $\mathrm{CH}_{4}$ is twice as high in the Northern than in the Southern Hemisphere, given large summer effluxes from 
North American bogs and tundra (Reeburgh and Whalen 1992) and modest $\mathrm{CH}_{4}$ fluxes from Siberian wetlands (Christensen et al. 1995). Between August and April, 5.8 $\mathrm{Tg}$ of $\mathrm{CH}_{4}$ accumulates in the atmosphere north of $60^{\circ} \mathrm{N}$. Highlatitude winter fluxes measured previously were only $10-12 \%$ of the annual total (Whalen and Reeburgh 1988, Whalen and Reeburgh 1992), an insufficient flux to explain a winter maximum in atmospheric $\mathrm{CH}_{4}$. Our research provides evidence for a large winter $\mathrm{CH}_{4}$ source from Siberian lakes.

In the Pleistocene, most of the northern Siberian plains were unglaciated and accumulated $\sim 400,000 \mathrm{Tg}$ of organic carbon in sediments (mainly derived from plant roots), similar to the total carbon in the terrestrial biosphere. These sediments contained abundant ice ( 40 to $70 \%$ of soil volume), which began melting during the Holocene to form thermokarst (thaw) lakes that now make up $\sim 30 \%$ of the landscape. These lakes migrated across the north Siberian plains during the Holocene, releasing to the atmosphere an average of $170-220 \mathrm{~g} \mathrm{C}$ $\mathrm{m}^{-2} \mathrm{yr}^{-1}$, including $\sim 16 \mathrm{~g} \mathrm{CH}_{4} \mathrm{~m}^{-2} \mathrm{yr}^{-1}$; we estimate that half of this $\mathrm{CH}_{4}$ was derived from Pleistocene carbon. Siberian lake sediments produce $\mathrm{CH}_{4}$ bubbles in lakes throughout the year (Zimov and Govorushko 1979), particularly near shores with active erosion. During winter, the bubbles form koshkas, which are flat bubbles of $\mathrm{CH}_{4}$ in lake ice separated by ice films that periodically sublimate and release $\mathrm{CH}_{4}$ to the atmosphere. In areas where $\mathrm{CH}_{4}$ ebullition (bubbling) is most active, channels through the ice remain open all winter.

To evaluate the significance of this source, we incubated Pleistocene sediments from an eroding lakeshore with lake water. The yield was $65 \pm 3 \mathrm{mg}$ $\mathrm{CH}_{4} \mathrm{~g}^{-1}$ sediment at $15^{\circ} \mathrm{C}$ (mean $\pm \mathrm{SE}, \mathrm{n}=3$ ) over 12 months, equivalent to $5 \%$ of the carbon originally present in the soil; $26 \pm 2 \mathrm{mg} \mathrm{CH} 4 \mathrm{~g}^{-1}$ were emitted at $3.5^{\circ} \mathrm{C}$, and $19 \pm 2 \mathrm{mg} \mathrm{CH}_{4} \mathrm{~g}^{-1}$ were emitted at $0^{\circ} \mathrm{C}$. These data indicate that the carbon in Pleistocene sediments is sufficiently labile to support methanogenesis and that, although methanogenesis is temperature-sensitive, it occurs at substantial rates at 0 to $3.5^{\circ} \mathrm{C}$.

To test whether methanogenesis in lake sediments is currently fueled by Pleistocene-aged organic matter, we measured stable and radiocarbon isotopes of $\mathrm{CH}_{4}$ emitted by ebullition from two representative thaw lakes near Cherskii, Republic of Sakha (Yakutia), Russia $\left(69^{\circ} \mathrm{N}, 161^{\circ} \mathrm{E}\right) . \mathrm{CH}_{4}$ collected from these lakes in winter (April) had an average ${ }^{14} \mathrm{C}$ age of $27,200 \mathrm{yr}$. This age indicates that Pleistocene sediments deposited $20,000-40,000{ }^{14} \mathrm{C}$ years ago contributed $68-100 \%$ of $\mathrm{CH}_{4}$ flux from these lakes. In contrast, $\mathrm{CH}_{4}$ emitted in the summer (July) had an average ${ }^{14} \mathrm{C}$ age of $9,200 \mathrm{yr}$, indicating that Pleistocene carbon fueled $23-46 \%$ of summer methanogenesis and thus that more $\mathrm{CH}_{4}$ was produced in the younger surface sediments, which are warmer in summer than winter. Thus about half of current annual methanogenesis is 
fueled by Pleistocene carbon. In contrast, $\mathrm{CH}_{4}$ from Alaskan lakes was only 200 yr old because Alaska lacks extensive Pleistocene sediments.

The $213 \mathrm{C}$ value of $\mathrm{CH}_{4}$ collected from Siberian lakes was -71 to -73 . This value is less than that produced in summer by Alaskan tundra lakes or North American wet tundra. These values imply that the Siberian winter-collected $\mathrm{CH}_{4}$ was not as oxidized as in these other environments, or that there was an isotopic difference in substrate or a different pathway of methanogenesis. The hydrogen isotopic composition of the $\mathrm{CH}_{4}$ was variable, but most samples from the Siberian lakes were low $(\partial D=-370)$, indicative of a biotic source for $\mathrm{CH}_{4}$, low oxidation rates in the water column, and $\mathrm{CH}_{4}$ production by fermentation.

We measured $\mathrm{CH}_{4}$ ebullition fluxes from two thaw lakes using large funnels suspended beneath the ice. $\mathrm{CH}_{4}$ fluxes were generally highest from October to January, when deep sediments had their annual thermal maximum. Fluxes were highly variable within a season; fluxes were highest at times of low atmospheric pressure, as in north temperate lakes. The average $\mathrm{CH}_{4}$ ebullition flux in centers of lakes was $4.7 \pm 2.3 \mathrm{mg} \mathrm{CH}_{4} \mathrm{~m}^{-2} \mathrm{~d}^{-1}$. Near eroding lakeshores, fluxes were so high that they frequently overturned the collection funnels; the flux emitted from open holes in the ice was $56 \mathrm{mg} \mathrm{CH}_{4} \mathrm{~m}^{-2} \mathrm{~d}^{-1}$. In addition to open holes, there were koshkas containing 1-100 I of $50 \% \mathrm{CH}_{4}$ that vent $\mathrm{CH}_{4}$ several times each winter and provide an additional unquantified $\mathrm{CH}_{4}$ source. Sediments in these lakes released $22 \mathrm{~g} \mathrm{CH}_{4} \mathrm{~m}^{-2}$ in September, when we disturbed the sediments, but $<5 \mathrm{~g} \mathrm{CH}_{4} \mathrm{~m}^{-2}$ a month later. This large $\mathrm{CH}_{4}$ release over one month provides independent evidence for a large $\mathrm{CH}_{4}$ ebullition flux.

$\mathrm{CH}_{4}$ can also move to the atmosphere in winter in overflow, when the weight of winter snow pushes the ice below the equilibrium water level of the lake. The $\mathrm{CH}_{4}$ concentration in overflow water decreases from $1.7 \mathrm{mg} \mathrm{CH}_{4} \mathrm{I}^{-1}$ to $<0.01 \mathrm{mg} \mathrm{CH}_{4} \mathrm{H}^{-1}$. The $30 \mathrm{~cm}$ of overflow that typically acccumulate on lakes of the forest zone would thus release $0.52 \mathrm{~g}$ of dissolved $\mathrm{CH}_{4} \mathrm{~m}^{-2} \mathrm{yr}^{-1}$.

The average summer diffusive flux measured in 19 lakes along a climate transect inland from the Arctic Ocean was $7.6 \pm 1.4 \mathrm{mg} \mathrm{CH}_{4} \mathrm{~m}^{-2} \mathrm{~d}^{-1}$, a value similar to that in Alaskan lakes. The 19 lakes had $3.1 \pm 0.7 \mathrm{mg} \mathrm{m}^{-2}$ of dissolved $\mathrm{CH}_{4}$ in March, indicating that winter accumulation of $\mathrm{CH}_{4}$ is typical of north Siberian lakes.

We estimate the total annual flux of $\mathrm{CH}_{4}$ for the lakes in our study region to be at least $7 \mathrm{~g} \mathrm{CH}_{4} \mathrm{~m}^{-2} \mathrm{yr}^{-1}, \sim 50 \%$ of the potential flux we estimated $16 \mathrm{~g}$ $\mathrm{CH}_{4} \mathrm{~m}^{-2} \mathrm{yr}^{-1}$ ) from regional carbon inputs to lakes. Approximately $75 \%$ of this flux occurs in winter. If these fluxes are typical of Siberian lakes, these lakes would emit $\sim 1.5 \mathrm{Tg} \mathrm{CH}_{4}$ in winter ( $2 \mathrm{Tg} \mathrm{CH}_{4}$ annually). This is small relative to 
global sources (Cicerone and Oremland 1988) but is $25 \%$ of the high-latitude winter accumulation of $\mathrm{CH}_{4}$ in the atmosphere. If high-latitude warming trends (Chapman and Walsh 1993, Serreze et al. In press) continue, thawing of permafrost would increase, and methane flux from Siberian thaw lakes would act as a positive feedback to climate warming.

Structural accomplishments

In addition to the research findings of the past three years, there have been several tangible advances in the structural capabilities to do globalchange research in Russia that have resulted from our DOE research. This research built on a pre-existing monitoring program of $\mathrm{CO}_{2}$ exchange in forest tundra initiated by Zimov and colleagues in 1989. The DOE research enabled him to continue these measurements with improved instrumentation (Licor 6200 portable infrared gas analyzer) and to expand his monitoring of $\mathrm{CO}_{2}$ exchange from a single forest-tundra site to 10 sites that include all the major ecosystem types of northern Siberia (see research results). Carbon exchange has been measured at weekly intervals throughout the annual cycle since June 1995 and will continue to be monitored in the future. The 9-yr data base for forest tundra is the longest record of regular carbon exchange measurements that we are aware of in any ecosystem. We have developed an AVHRR-based vegetation map of the Kolyma lowlands, from which we will estimate regional carbon exchange.

Our DOE research program contributed substantially to the role that Zimov and the Northeast Science Station can contribute to international research on global change. His station now has several computers and email and internet access. During the year that Zimov and his wife (also a researcher at the Northeast Science Station) spent in Berkeley, they substantially improved their English and became proficient in use of spreadsheet and graphics programs. Zimov presented his work at two meetings and established a new research collaboration with S. Tyler to monitor concentrations and isotopic composition of atmospheric $\mathrm{CO}_{2}$ and $\mathrm{CH}_{4}$ in Cherskii.

The DOE research also enabled Chapin to learn considerably more about the ecology of Siberia, its Pleistocene history, and the factors that might govern its future trace-gas feedbacks to climate. Discussions with Zimov and colleagues provided Chapin with a much broader intellectual framework from which to think about terrestrial feedbacks to climate.

Remaining funds

All funds awarded in this grant were spent.

Publications from DOE research 
Bonan, G.B., F.S. Chapin, III, and S.L. Thompson. 1995. Boreal forest and tundra ecosystems as components of the climate system. Climatic Change 29:145-167.

Zimov, S.A., V.I. Chuprynin, A.P. Oreshko, F.S. Chapin, III, M.C. Chapin, and J.F. Reynolds. 1995. Effects of mammals on ecosystem change at the Pleistocene-Holocene boundary. Pages 127-135 In: F. S. Chapin, III, and Ch. Körner, eds. Arctic and Alpine Biodiversity: Patterns, Causes and Ecosystem Consequences. Springer-Verlag, Berlin.

Zimov, S. A., V. I. Chuprynin, A. P. Oreshko, F. S. Chapin, III, J. F. Reynolds, M. C. Chapin. 1995. Steppe-tundra transition: an herbivore-driven biome shift at the end of the Pleistocene. Am. Nat. 146:765-794.

Chapin, F. S., III, M.S. Bret-Harte, S.E. Hobbie, and H. Zhong. 1996. Plant functional types as predictors of the transient response of arctic vegetation to global change. J. Veg. Sci. 7:347-358.

Chapin, III, S.A. Zimov, G.R. Shaver, and S.E. Hobbie. 1996. $\mathrm{CO}_{2}$ fluctuation at high latitudes. Nature 383: 585-586.

Zimov, S.A., S.P. Davidov, Y.V. Voropaev, S.F. Prosiannikov, I.P. Semiletov, M.C. Chapin, and F.S. Chapin, III. 1996. Siberian $\mathrm{CO}_{2}$ efflux in winter as a $\mathrm{CO}_{2}$ source and cause of seasonality in atmospheric $\mathrm{CO}_{2}$. Climatic Change 33:1 $11-120$

Chapin, F.S., III, S.E. Hobbie, and G.R. Shaver. 1997. Impacts of global change on composition of arctic communities: Implications for ecosystem functioning. Pages 221-228 In Global change and arctic terrestrial ecosystems. W.C. Oechel, T. Callaghan, T. Gilmanov, J.I. Holten, B. Maxwell, U. Molau, and B. Sveinbjörnsson (eds.). Springer-Verlag, New York.

Chapin, F. S., III, J. P. MCFadden, and S.E. Hobbie. 1997. The role of arctic vegetation in ecosystem and global processes. Pages 97-112 In Ecology of arctic environments. (S. J. Woodin and M. Marquiss, eds.) Blackwell Science, Oxford.

Zimov, S.A., Y.V. Voropaev, I.P. Semiletov, S.P. Davidov, S.F. Prosiannikov, F.S. Chapin, III, M.C. Chapin, S. Trumbore, and S. Tyler. 1997. North Siberian lakes: a methane source fueled by Pleistocene carbon. Science 277:800802.

Verville, J.H., S.E. Hobbie, F.S. Chapin, III, and D.U. Hooper. 1998. Response of tundra $\mathrm{CH}_{4}$ and $\mathrm{CO}_{2}$ flux to manipulation of temperature and vegetation. Biogeochemistry 41:215-235.

Mooney, H.A., J. Canadell, F.S. Chapin, III, J.R. Ehleringer, Ch. Körner, R.E. McMurtrie, W.J. Parton, L.F. Pitelka, E.-D. Schulze. 1999. Ecosystem physiology responses to global change. Pages 141-189 In: The terrestrial biosphere and global change: Implications for natural and managed ecosystems (B. Walker, W. Steffen, J. Canadell, and J. Ingram, eds). Cambridge Univ. Press, Cambridge. 
Zimov, S.A., S.P. Davidov, G.M.Zimova, A.I. Davidova, F.S. Chapin, III, M.C. Chapin, and J.F. Reynolds. 1999. Contribution of disturbance to highlatitude amplification of atmospheric $\mathrm{CO}_{2}$. Science 284: 1973-1976.

Chapin, F.S., III, A.D. McGuire, J. Randerson, R. Pielke, Sr., D. Baldocchi, S.E. Hobbie, N. Roulet, W. Eugster, E. Kasischke, E.B. Rastetter, S.A. Zimov, and S.W. Running. In press. Arctic and boreal ecosystems of western North America as components of the climate system. Global Change Biology

Kittel, T.G.F., W.L. Steffen, and F.S. Chapin, III. In press. Global and regional modeling of arctic-boreal vegetation distribution and its sensitivity to altered forcing. Global Change Biol.

Serreze, M.C., J.E. Walsh, F.S. Chapin, III, T. Osterkamp, M. Dyurgerov, V. Romanovsky, W. Oechel, F. Morison, T. Zhang, and R.G. Barry. In press. Observational evidence of recent change in the northern high-latitude environment. Climatic Change.

Shaver, G.R., J. Canadell, F.S. Chapin, III, J. Gurevitch, J. Harte, G. Henry, P. Ineson, S. Jonasson, J. Melillo, L. Pitelka, and L. Rustad. In press. Global warming and terrestrial ecosystems: A conceptual framework for analysis. BioScience.

Published meeting abstracts from DOE research

Zimov, S.A., Y.V. Voropaev, I.P. Semiletov, S.P. Davydov, S.F. Prosiannikov, F.S. Chapin, III, M.C. Chapin, S. Trumbore, and S. Tyler. 1996. Pleistocene-aged methane emitted by North Siberian lakes: impact on the seasonal dynamics of atmospheric methane concentration. American Geophysical Union Fall Meeting.

Zimova, G., S. Zimov, S. Davydov, A. Davydova, F.S. Chapin, III, and M.C. Chapin. 1996 Experimental evidence for the impact of past and present biome changes on the seasonal dynamics of atmospheric $\mathrm{CO}_{2}$ concentration. American Geophysical Union Fall Meeting.

Chapin, F.S., III, J. McFadden, and W. Eugster. 1997. Effects of arctic vegetation on regional water and energy exchange in present and future climates. Bull. Ecol. Soc. Amer. 78.

Grogan, P. and F.S. Chapin, III. 1997. Belowground $\mathrm{CO}_{2}$ flux in Alaskan tundra: effects of climate and vegetation type with regional extrapolation. Bull. Ecol. Soc. Amer. 78.

References in this report

Chapin, F. S., III, M. S. Bret-Harte, S. E. Hobbie, and H. Zhong. 1996. Plant functional types as predictors of the transient response of arctic vegetation to global change. Journal of Vegetation Science 7:347-358.

Chapman, W. L., and J. E. Walsh. 1993. Recent variations of sea ice and air temperature in high latitudes. Bulletin of the American Meteorological Society 74:33-47. 
Christensen, T. R., S. Jonasson, T. V. Callaghan, and M. Havström. 1995. Spatial variation in high latitude methane flux along a transect across Siberian and European tundra environments. Journal of Geophysical Research 100D:21035-21045.

Cicerone, R. J., and R. S. Oremland. 1988. Biogeochemical aspects of atmospheric methane. Global Biogeochemical Cycles 2:299-327.

Fan, S. M., M. L. Goulden, J. W. Munger, B. C. Daube, P. S. Baldwin, S. C. Wofsy, J. S. Amthor, D. R. Fitzjarrald, K. E. Moore, and T. R. Moore. 1995.

Environmental controls on the photosynthesis and respiration of a boreal lichen woodland: a growing season of whole ecosystem exchange measurements by eddy correlation. Oecologia 102:443-452.

Flannigan, M. D. F., and C. E. Van Wagner. 1991. Climate change and wildfire in Canada. Canadian Journal of Forest Research 21:66-72.

Fung, I., J. John, J. Lerner, E. Matthews, M. Prather, L. P. Steele, and P. J. Fraser. 1991. 3-dimensional model synthesis of the global methane cycle. Journal of Geophysical Research 96:13033-13065.

Goulden, M. L., and P. M. Crill. In press. Automated measurements of $\mathrm{CO}_{2}$ exchange at the moss surface of a black spruce forest. Journal of Geophysical Research

Khalil, M. A. K., and R. A. Rasmussen. 1983. Sources, sinks and seasonal cycles of atmospheric methane. Journal of Geophysical Research 88:5131-5144.

Myneni, R. B., C. D. Keeling, C. J. Tucker, G. Asrar, and R. R. Nemani. 1997. Increased plant growth in the northern high latitudes from 1981-1991. Nature 386:698-702.

Oberbaver, S. F., and W. C. Oechel. 1989. Maximum $\mathrm{CO}_{2}$-assimilation rates of vascular plants on an Alaskan arctic tundra slope. Holarctic Ecology 12:312-316.

Oechel, W. C., S. J. Hastings, G. Vourlitis, M. Jenkins, G. Riechers, and N. Grulke. 1993. Recent change of Arctic tundra ecosystems from a net carbon dioxide sink to a source. Nature 361:520-523.

Oechel, W. C., and B. Sveinbjörnsson. 1978. Primary production processes in arctic bryophytes at Barrow, Alaska. Pages 269-298 in L. L. Tieszen, editors. Vegetation and production ecology of an Alaskan arctic tundra. Springer-Verlag, Heidelberg.

Reeburgh, W. S., and S. C. Whalen. 1992. High latitude ecosystems as $\mathrm{CH}_{4}$ sources. Ecological Bulletin 42:62-70.

Serreze, M. C., J. E. Walsh, F. S. Chapin III, T. Osterkamp, M. Dyurgerov, V. Romanovsky, W. C. Oechel, J. Morison, T. Zhang, and R. G. Barry. In press. Observational evidence of recent change in the northern high-latitude environment. Climatic Change

Shaver, G. R., and F. S. Chapin III. 1991. Production:biomass relationships and element cycling in contrasting arctic vegetation types. Ecological Monographs 61:1-31. 
Viereck, L. A. 1973. Wildfire in the taiga of Alaska. Quaternary Research 3:465495.

Whalen, S. C., and W. S. Reeburgh. 1988. A methane flux time series for tundra environments. Global Biogeochemical Cycles 2:399-409.

Whalen, S. C., and W. S. Reeburgh. 1992. Interannual variations in tundra methane emission: a 4 -year time series at fixed sites. Global biogeochemical cycles 6:139-159.

Zimov, S. A., S. P. Davidov, Y. V. Voropaev, and S. F. Prosiannikov. 1993. Planetary maximum $\mathrm{CO}_{2}$ and ecosystems of the north. Pages 21-34 in T. S. Vinson, and T. P. Kolchugina, editors. Carbon cycling in boreal forest and sub-arctic ecosystems: Biospheric responses and feedbacks to global climate change.

Zimov, S. A., S. P. Davidov, Y. V. Voropaev, S. F. Prosiannikov, I. P. Semiletov, M. C. Chapin, and F. S. Chapin III. 1996. Siberian $\mathrm{CO}_{2}$ efflux in winter as a $\mathrm{CO}_{2}$ source and cause of seasonality in atmospheric $\mathrm{CO}_{2}$. Climatic Change 33:111-120.

Zimov, S. A., and S. M. Govorushko. 1979. lavlenie izbiratel'nogo taianiia ozernogo l'da. Materialy Glatsiologicheskikh Issledovanii 37:

Zimov, S. A., G. M. Zimova, S. P. Davidov, A. I. Davidova, Y. V. Voropaev, Z. V. Voropaeva, S. F. Prosiannikov, O. V. Prosiannikova, I. V. Semiletova, and I. P. Semiletov. 1993. Winter biotic activity and production of $\mathrm{CO}_{2}$ in Siberian soils: A factor in the greenhouse effect. Journal of Geophysical Research 98D:5017-5023. 